\title{
Grundtvig som stridsmand og polemiker
}

\author{
Vanja Thaulow
}

Denne artikel er baseret på ph.d.-afhandlingen Herrens Stridsmand. Retorisk kritik afN.F.S. Grundtvigs teologiske polemik i perioden 1810-1825. Afhandlingen er en undersøgelse af Grundtvigs polemiske retorik i den såkaldt 'bibelkristne' periode af forfatterskabet, særligt årene 1810-1815. Undersøgelsen angår både den polemik, der findes på tværs af genrer, og den egentlig polemiske genre stridsskriftet, som har været noget overset i forskningen. Jeg har valgt at udforme undersøgelsen som en retorisk analyse og kritik, fordi det moderne retorikfag har et stort og udviklet begrebsapparat, som er velegnet til at analysere de elementer, der er på spil i polemiske tekster: forfatterens selvfremstilling, publikumskonstruktion, argumentation og stil. ${ }^{1}$ Nærmere bestemt er undersøgelserne foretaget som en række retoriske nærlæsninger af udvalgte værker. Jeg kan hverken udfolde den retoriske teori eller mine nærlæsninger her i artiklen. Jeg kan blot opsummere resultaterne af mine undersøgelser, og de tegner et noget andet billede af Grundtvig end den rummelige kirke- og landsfader, han er kendt som. Grundtvig optrådte i denne periode som 'herrens stridsmand' og som en domsprofet, der søgte indflydelse på sit læsepublikum ved hjælp af postulerende og polemisk-provokerende retorik. I de personlige pennefejder, Grundtvig var involveret i, opførte han sig ikke blot polemisk, men decideret eristisk. Han gik ind i og ud af en debat overbevist om, at han selv havde ret. Hans mål var ikke at overbevise (eller lade sig overbevise) af gode argumenters vægt, men simpelthen at besejre sin modstander eller ligefrem udgrænse denne socialt.

${ }^{1}$ Der findes ikke mange eksempler på egentlige retoriske analyser i Grundtvig-forskningen. Det mest omfattende studie er amerikaneren Paul Merville Larsons disputats fra 1942 med titlen A Rhetorical Study of Bishop Nicholas [sic!'] Frederick Severin Grundtvig. Larsons forskningsinteresse var Grundtvig som taler, og som sådan var han et barn af sin tid. Den amerikanske videnskabelige retorik var nemlig i denne periode især optaget af store mænds taler. Sidenhen er retorikkens genstandsområde blevet udvidet betragteligt. Et nyere dansk studie med en retorisk tilgang til Grundtvigs forfatterskab er antologien Ved Lejlighed. Grundtvig og genrerne, hvor forfatterne undersøger Grundtvigs genrebrug både litterært og retorisk (Auken og Sunesen (red.) 2014). 


\section{"Krigsmand af Princip"}

Man skal ikke have læst mange af Grundtvigs værker fra perioden 18101825 for at bemærke, at han førte en meget gennemgribende og aggressiv polemik imod sin 'vantro' samtid i almindelighed og de rationalistiske teologer og præster i særdeleshed. Han reagerede kraftigt på enhver tendens i samtiden til at ophøje menneskets fornuft eller følelse på bekostning af troen og kritiserede såvel rationalismen som den romantiske filosofi. Grundtvigs polemiske adfærd hang sammen med hans teologiske tænkning i denne periode. Efter sin krise og omvendelse i 1810-1811 regnede han kristendommen for absolut og ufravigelig sandhed. Hans teologi var strengt bibelsk og præget af især profetbøgerne, Johannesevangeliet og Johannes' Åbenbaring. Grundtvigs opfattelse af virkeligheden var som følge heraf dualistisk og hans syn på verden og mennesket meget negativt. Han havde desuden en stærk bevidsthed om tidernes ende og dommedag, hvilket gjorde al hans tale meget akut. Han så det som sin opgave at vidne om kulturens og troens forfald og revse folket for at få dem til at omvende sig, før det var for sent. Han ville tvinge folk til øjeblikkelig afgørelse for eller imod sandheden.

Grundtvigs polemik mod omverden udsprang af denne særlige form for kristentro og især af hans stærke kaldsbevidsthed. I 1811 aflagde han som bekendt præsteløftet (egl. den latinske præsteed fra Kirkeritualet 1685), og han tog især passagen om at bekæmpe falske lærdomme meget alvorligt. ${ }^{2}$ For Grundtvig var polemikken en funktion af kaldet og af præsteløftet. Han forsikrer således flere steder om, at han ikke strider af lyst, men striden er hans "Kalds og Embeds Lov" (Grundtvig 1815b, 1637), og han er mere "Krigsmand af Princip end af Natur" (Grundtvig 1877, 480). ${ }^{3}$ Flere steder legitimerer han sin polemik ved at henvise til præsteløftet. Grundtvig anser altså striden for nødvendig og det teologiske had - odium theo-

2 Passagen om at bekæmpe falske lærdomme var formuleret noget skarpere i præsteeden fra 1685 end i det senere præsteløfte fra 1871. Præsterne skulle aflægge ed på, at de ville 'fly og afsky' den lære, der står Gud imod, idet de ønskede "hellere mit Blod at maatte udgyde end falske og afsindige Lærdomme at skulle bifalde" (Danmarks og Norgis Kirke-Ritual. 1685-1985, 190).

3 Man kan nu nok ikke komme udenom, at Grundtvig også var polemisk af natur. Larson skriver i sin konklusion: "By nature he was aggressive, vigorous and deeply conscientious" (1942, 324). 
logicum - for uomgængeligt. Hans kristendomsforståelse må bestemmes som ret radikal, når han i $\mathrm{Om}$ Polemik og Tolerance hævder, at intolerance er en vigtig kristen værdi (Grundtvig 1941), og når han i prædikenen Den christelige Kamp opfordrer sine medkristne til at nære "et aandeligt, et himmelsk, et sandhedskiærligt Had" til Guds fjender (Grundtvig 1825b, 12).

Med inspiration i bibelsteder som 2 Tim 2,3 og Ef 6,11-17 ser Grundtvig i denne periode sig selv som en herrens stridsmand, der kæmper med Guds ord som våben. Han henviser ofte til Hebr 4,12, der siger, at Guds ord er "skarpere end noget tveægget sværd [...] og er dommer over hjertets tanker og meninger", og han bruger netop Bibelen til at dømme sin omverden. Han ser det som præstens opgave at "lade Herren dømme" og "udsige hans Ords Domme" (Grundtvig 1941, 100). Som Helge Toldberg har formuleret det, optræder Grundtvig i disse år som "det skaanselsløse talerør for ecclesia militans" (1950, 31 f.). Hans forbillede i denne rolle er først og fremmest Martin Luther, som han ofte omtaler som stridsmand (fx Grundtvig 1815b, 1639), og hvis polemiske retorik, han lovpriste: "Ingen talde skarpere end Morten Luther" (Grundtvig 1814b, 26). ${ }^{4}$

\section{Den polemiske retorik på tværs af genrer}

Den teologiske polemik i forfatterskabet 1810-1825 kan inddeles i to hovedformer. Der er dels den 'brede' polemik, som består i en almen kritik og revselse af tidsånden og præstestanden, og som optræder i mange forskellige genrer; dels den personlige polemik, som udfolder sig i pennefejder, særligt i den genre, som Grundtvig kaldte "Feidebrev" eller "Stridsskrift". Med hensyn til den brede polemik kan det konstateres, at man kan finde polemiske udfald i stort set alle genrer i perioden 1810-1825, selv i en subskriptionsindbydelse. Jeg har undersøgt nogle af de mest polemiske og konfrontatoriske værker, nemlig hans dimisprædiken Hvi er Herrens

\footnotetext{
${ }^{4}$ Grundtvig opfattede som bekendt sig selv som en ny Luther i Norden: "Kald mig i Spot kun Lutherlil! / Jeg skal til Navnet svare" (Grundtvig 1812c, 10).

5 I subskriptionsindbydelsen til en prædikensamling, som Grundtvig påtænkte at udgive i 1812, er der således en tydelig brod mod præster, som ikke prædiker bibelsk, hvad der efter Grundtvigs opfattelse er "den eneste kristelige" prædikemåde (Grundtvig 1812a, 1).
} 
Ord forsvundet af hans Hus? fra 1810, den i samtiden utrykte landemodetale "Om Polemik og Tolerance" fra 1814 og historiebogen Kort Begreb af Verdens Krønike i Sammenhang fra 1812 (herefter VK 1812). I et utrykt manuskript i Grundtvig-arkivet kan man finde nogle ret interessante udtalelser om sidstnævnte værk. I en replik til Christian Molbech om, hvorvidt en historiebog må være teologisk og polemisk i sit anliggende, skriver Grundtvig: "naar Man kalder den [VK 1812] en theologisk Polemik (et Stridsskrift for Lærdomme Guds Ord) da har Man netop fundet det Navn jeg ønsker hvert Skrift fra mig maatte bære med Føie”. ${ }^{6}$ Her har vi altså en form for programerklæring for forfatterskabet i disse år. Alle værker, uanset genre, er i hensigten en form for teologisk polemik. Denne hensigtserklæring stemmer godt overens med det, som mine retoriske analyser af værkerne viser.

Det første påfaldende træk ved de værker, jeg har nærlæst, er, at Grundtvig konstruerer den retoriske situation, herunder exigence (det påtrængende problem, som han søger at løse), næsten ens i alle sine tekster. ${ }^{7}$ Det overordnede problem er hver gang, at tiden er 'vanartig', og at kristentroen er ved at gå til grunde. Grundtvigs intention er tilsvarende at vække folket til tro og eftertanke, ja, ligefrem at 'frelse' dem, ved at pege på den vantro og det store hovmod, som findes i tiden. Tanken er, at når folk først indser,

${ }^{6}$ Fasc. 161.1. i Grundtvig-arkivet, betitlet "Indledning", blad 2v. Udkastet er formentlig fra foråret 1813. Ordet "Lærdomme" er streget ud i kladden.

7 Begrebet 'den retoriske situation' stammer oprindeligt fra Bitzer (1997/1968), som ville gøre op med tanken om, at det er taleren og dennes persuasive intention, som er den primære kilde til retorisk aktivitet. Trangen til at overbevise opstår if. Bitzer ikke ud af den blå luft, men en tale eller en tekst opstår som reaktion på en bestemt situation. Den retoriske situation er if. Bitzer bestemt af tre elementer: det påtrængende problem (exigence), som taleren eller forfatteren ønsker at afhjælpe retorisk; det publikum, han ønsker at påvirke (audience), og de retoriske vilkår, han er underlagt (constraints). Bitzer er sidenhen blevet korrigeret af bl.a. Vatz (1973), som indtager et mere konstruktivistisk synspunkt. If. Vatz kan man ikke tale om, at den retoriske situation foreligger som en objektiv observerbar kendsgerning, men situationen er noget, der skabes i talerens fortolkning af omstændighederne og formidling af disse. Når jeg ovenfor skriver, at Grundtvig konstruerer den retoriske situation på en bestemt måde, er det altså, fordi jeg tilslutter mig Vatz' synspunkt. Exigence er ikke noget, der foreligger i situationen, men noget, forfatteren ser i situationen. 
hvor galt det står til, vil de omvende sig og gå ind i kampen for sandheden (se fx Grundtvig 1813, 24).

Til sit formål optræder Grundtvig i forskellige roller (personae) over for sit læsepublikum. Ud over rollen som herrens stridsmand er det især rollen som domsprofet, han benytter. Flemming Lundgreen-Nielsen konkluderer i Det handlende ord (1980), at Grundtvig måske havde en følelse af at være "profetisk forkynder som GTs seere" (883). På baggrund af de retoriske analyser kan der svares med større overbevisning: Grundtvig konstruerer helt gennemført en profetrolle at tale ud fra. Især $V K 1812$ er stærkt præget af profet-retorik. Hermed menes ikke primært, at Grundtvig spår om fremtiden (det gør han indimellem), heller ikke, at han optræder som en særligt privilegeret gudelig fortolker af profeternes tale (det gør han ofte), men især, at han optræder som dommer over samtiden på samme måde, som de gammeltestamentlige profeter gjorde. De gammeltestamentlige skriftprofeters funktion bestod ikke primært i at spå om fremtiden, men i at dømme og revse den vantro samtid. De varslede dom over samtiden, både over folket og over enkeltpersoner (typisk magthavere), og optrådte som Guds vidner mod folket. Det er præcis det, Grundtvig gør i $V K 1812 .^{8}$

Med en selvfremstilling som profet tildeler Grundtvig sig selv en særlig taleposition. Som profet har han en ophøjet status og en særlig viden om, hvordan alting hænger sammen. Han er nærmest en alvidende gudelig fortolker. Desuden kan han som en liminal figur, der befinder sig på kanten af samfundet, tillade sig at revse folket. Profetrollen har den fordel, at den giver legitimitet til kritikken af samfundet og af navngivne personer. Fordi kritik er en fast del af profetens virke, behøver den, der taler som en profet, ikke at forklare eller forsvare sin ret til at ytre kulturel og politisk kritik. Hvis publikum accepterer taleren i rollen, vil de også acceptere kritikken. ${ }^{9}$

${ }^{8}$ If. Grundtvigs brug af ordet 'dixi' i flere tekster fra denne periode. Det alluderer til profetudtrykket "dixi et salvavi animam meam" (en sammenskrivning af 1 Mos 19,17 og Ez 3,19 i Vulgatas version). Ordret betyder det 'jeg har talt og frelst min sjæl', men i den gammeltestamentlige sammenhæng har det en mere omfattende betydning i retning af 'nu har jeg talt (dvs. advaret jer), og jeg har ikke noget ansvar, hvis I ikke vil rette jer efter, hvad jeg har sagt'.

9 Det skal nævnes, at Grundtvig selv afviste at vare en profet (bl.a. over for H.C. Ørsted, som havde kritiseret ham for at tro, at han var en 'af Gud indblæst pro- 
Beslægtet med profetrollen er 'parrhesiasten', dvs. en person, der kan sige alt, og som ikke er bange for at tale magthaverne imod, uanset hvilke konsekvenser det måtte få. ${ }^{10}$ En 'parrhesiast' taler sandhed med stor frimodighed, kraft og selvsikkerhed, alt imens han løber en stor personlig risiko. Sådan fremstiller Grundtvig ofte sig selv. Han iscenesætter sig selv som en uforfærdet 'djærv' forkynder, der i en farlig tid tør tale en ildehørt sandhed til samtiden. Han vil gerne fremstå som 'den modige taler', der tør tale tidens dominerende og magtfulde teologer midt imod, og han var vitterligt også modig, idet hans personangreb jo ikke var uden risiko. Trykkefrihedsforordningen 1799 satte grænser for, hvad der kunne trykkes.

Den sidste rolle, der skal nævnes her, er rollen som martyr. Da Grundtvig i 1814-1815 var blevet træt af ikke at blive hørt og taget alvorligt, fandt han ind i martyrrollen. Han klagede over at blive forfulgt og blive regnet for "den Ringeste blandt Sjællands Præster" (Grundtvig 1941, 104). Martyrrollen brugte han til at pege på modstandernes ondskab og gøre sig selv til offer. Samtidig stadfæstede denne konstellation hans identitet som særligt udvalgt og kaldet, idet han tog den manglende succes som forkynder som et tegn på, at han virkelig var et sandhedsvidne.

Grundtvigs brug af disse forskellige roller som hhv. stridsmand, profet, parrhesiast og martyr bidrager til at sætte ham selv i centrum og i scene som en uomgængelig person i samtiden, én, man er nødt til at lytte til. Selvfremstillingen er efter min mening noget af det mest interessante ved Grundtvigs forfatterskab. Flemming Lundgreen-Nielsen har brugt begrebet "selvsymbolik" om hans særlige selvforståelse og selvfremstilling og vist, at Grundtvig ikke lod sig kue af modgangen i 1810-1815, men fortsat tænkte store tanker om sig selv og den rolle, han havde at udfylde

fet'), men man skal jo ikke altid tage en forfatters ord for pålydende - faktisk er det en topos i profetisk retorik, at man skal understrege, at man ikke er en profet. Der er nok ikke nogen efterbibelske forfattere, som vil hævde at være profeter på linje med Bibelens profeter - det ville være hovmodigt - men det forhindrer ikke, at man kan tale og agere som en profet.

10 'Parrhesia' er et omdiskuteret begreb i såvel filosofiske som retoriske kredse. Foucault har behandlet det indgående i sine sidste forelæsninger, udgivet under titlen Fearless Speech (2001). Han ser på sin vis begrebet som værende i opposition til retorikken, idet han forstår parrhesia som det modsatte af velformet og strategisk tale, mens Walzer (2013) viser, at parrhesia ikke er "artless", men "highly rhetorical". Parrhesia bruges ofte netop strategisk med et persuasivt sigte. 
i Danmark: Han forstod sin eksistens og sit virke som tegn for en snarlig gennembrydende åndelig fornyelse i Norden (1980, 885-892). ${ }^{11}$

Grundtvigs tekster rummer ud over den ovennævnte selvfremstilling også en bestemt publikumskonstruktion, med et moderne retorisk begreb 'the second persona' eller 'det indskrevne publikum' (Black 2013/1970). Det indskrevne publikum er forfatterens tekstinterne konstruktion af publikum, dvs. en model af, hvad skribenten ønsker, at hans faktiske publikum skal være eller blive. Det indskrevne publikum i Grundtvigs tekster fra 1810 til 1825 er først og fremmest en gruppe mennesker, som vil acceptere ham i rollen som profet og redskab for Guds ord. De er gudfrygtige folk, som vil adlyde 'sandhedens enlige stemme' i skikkelse af Grundtvig. De vil indvillige i at underordne fornuften under troen, og de vil uden videre tage såvel Bibelens som Grundtvigs ord for gode varer (det er, hvad Grundtvig indirekte forlanger, når han postulerer i stedet for at argumentere for sine synspunkter, mere herom nedenfor). Det indskrevne publikum er ydmyge mennesker, som frygter Guds dom, og som derfor er modtagelige over for advarende og irettesættende tale. At dømme efter reaktionerne på Grundtvigs tekster var der ikke mange blandt det faktiske publikum, som kunne identificere sig med dette publikumsbillede.

Det er påfaldende, at der i Grundtvigs tekster er indbygget en meget asymmetrisk relation til publikum, uanset om han henvender sig til de værste fjender, 'rationalisterne', eller de mere velvillige læsere, de 'gammeldags' kristne. Han er den, der kender verdens rette sammenhæng og kristendommens sandhed, og publikum er nødt til at give ham ret. Han tiltaler publikum i imperativer og truer dem med dom og straf, hvis de ikke tilslutter sig den rette tro og kampen for Guds sandhed. I et brev til Christian Molbech fra 1826 beskriver Grundtvig sin holdning til publikum i 1810'erne med følgende ord: "Jeg vilde som en luthersk Munk ikke med Haandens men dog med Mundens Vaaben tvinge Verden til ei blot at synes, men at være christelig" (Grundtvig og Molbech 1888, 140). Han

${ }^{11}$ Jf. Paaske-Lilien, hvor den ringeagtede bondeblomst står som et symbol både på opstandelsestroen og på Grundtvig selv: "Vinter-Storm og Hagl og Regn / Suser, bruser over Jorden, / Men jeg stander som et Tegn / For en Blomster-Tid i Norden” (Grundtvig 1817, 325). 
søger indflydelse på sit publikum ved hjælp af det, man kan kalde 'retorisk tvang. ${ }^{12}$

Kigger man nærmere på argumentation og stil i Grundtvigs polemiske tekster, mærker man også disse 'tvingende' træk ved hans retorik. Argumentationen er præget af tre forhold. For det første er egentlig argumentation ofte fraværende. Mange af Grundtvigs udsagn og fortolkninger er postulater. Han udtaler sine private meninger og domme, som om de var universelle sandheder. Kendetegnende for ham er udsagn som:

- "Det er soleklart, at ..." (fx 1815a, 60; 1825a, 36)

- Det er "upaatvivlelig vist" $(1813,66)$

- “Jeg veed jeg har Ret ...” $(1813,5)$

- "jeg veed, det er Sandhed" (1812b, XIX)

- “Er dette nu soleklart, som det jo unægtelig er ...” (1866/1827, 258)

At Grundtvig postulerer på denne måde, hænger højst sandsynligt sammen med hans forståelse af at være Guds talerør og profet. Profeten udsiger budskaber, der skal tages for pålydende, han argumenterer ikke. ${ }^{13}$

For det andet er argumentationen struktureret omkring modsætninger. Det var en præmis for Grundtvig, at der eksisterer et uophæveligt modsætningsforhold mellem Gud-Djævel, sandhed-løgn, godt-ondt, lys-mørke, og at disse størrelser nødvendigvis måtte bekæmpe hinanden. Når

${ }^{12}$ Udtrykket 'retorisk tvang' er min oversættelse af James McCroskeys begreb coercive power (2006, 102 f.). Ifølge McCroskey findes der fem måder, hvorpå man som taler eller skribent kan søge indflydelse på sit publikum. Man kan true med straf (coercive power) eller lokke med belønning (reward power); man peger på den ret, man har til at tale i kraft af sin rolle eller sit embede (legitimate power); man kan slå på sin viden og kompetence (expert power), eller man kan spille på den relation, man har til publikum (referent power). Det er min vurdering, at Grundtvig i perioden 1810-1815 benyttede sig af en kombination af den tvingende og retmæssige magt, som faktisk er de to typer, McCroskey advarer mod at bruge: "A source must be very careful when employing coercive or legitimate power. Receivers tend to resent both and want little to do with sources who employ them" (103).

${ }^{13}$ Larson når til samme konklusion i sine analyser af den ældre Grundtvigs taler: "One explanation of the confidence he placed in simple assertion was that he felt himself only a mouthpiece for making known the word of God" (1942, 330). 
han hos tænkere som F.W.J. Schelling og H.C. Ørsted stødte på andre synspunkter som at 'Gud udvikler sig' eller 'der er harmoni i verden', så beskyldte han dem for at sammenblande tilværelsens modsætninger og mente at kunne sætte dem på plads ved hjælp af "Modsigelsens Grundsætning" (kontradiktionsprincippet), der siger, at man ikke på samme tid kan bekræfte og benægte et udsagn. Hans argumentation for grundsætningen kan fx lyde sådan her:

Sandt kan ikke være Løgn, og Løgn ikke Sandhed, fordi Sandhed er Sandhed og kan ikke blive Løgn uden allerede at være det. Løgn kan ikke blive Sandhed, thi den maatte da tilintetgiøre sig selv, erklære sig selv for Løgn, være sig selv og ikke være det (Grundtvig 1813, 46 f.).

Grundtvig forsøgte ofte at fange sine modstandere i selvmodsigelser for så at bringe modsigelsens grundsætning på banen som en trumf, der fejer alle andre argumenter og synspunkter af bordet. Mod den praksis må man indvende, at modsigelsens grundsætning kun fungerer som et tvingende bevis inden for logikkens domæne, ikke inden for retorikken og dialektikken. I det naturlige sprog, som vi benytter, når vi diskuterer holdninger og værdier, er sætningen ikke logisk tvingende på samme måde. I nyretorikeren Chaïm Perelmans argumentationsteori henregnes brugen af kontradiktionsprincippet således til de kvasilogiske argumenter (Perelman 2005/1977, 91-119). Kvasilogiske argumenter ligner formelle ræsonnementer (logiske eller matematiske), men de adskiller sig fra den strenge formelle demonstration ved, at de altid forudsætter tilslutning til den tese eller det skema, som tillader argumentets anvendelse. Modsigelsens grundsætning forudsætter tilslutning til et strengt dualistisk skema, og princippet kan altså ikke bruges som et uimodsigeligt gendrivelsesmiddel mod folk, der ikke deler den dualistiske opfattelse. En kvasilogisk argumentation er ikke demonstration i logisk forstand, men fordi den ligner, kan den give indtryk af at være uantastelig. Når Grundtvig anvender modsigelsens grundsætning, låner han altså af den prestige, der er ved streng logisk tankegang, og forsøger at få argumentationen til at fremstå uimodsigelig. ${ }^{14}$

${ }^{14}$ Det er klart, at kontradiktionsprincippet har tiltalt Grundtvig, fordi det passede til hans dualistiske tankegang, men det er samtidig påfaldende, at han gør et logisk princip til sin kæphest, da han jo grundlæggende tager afstand fra det, der hører til logikkens domæne: matematikken, fornuften, de 'kløgtige' beslutninger. 
For det tredje har Grundtvigs argumentation ofte en stærk emotionel appel. Han benytter bl.a. autoritetsargumenter, som siger, at noget er sandt, fordi det står i Bibelen, eller fordi Luther har sagt det (etosappel), og han bruger motivationsargumenter, som truer og motiverer med frygt for dom og fortabelse (patosappel). Grundtvig benytter sig i det hele taget meget af både etos- og patosappel og knap så meget af logosappel (sml. Larson 1942, 189, 329).

Også Grundtvigs stil er præget af patos. Han benytter sig hyppigt af overdrivelser, som provokerer, krasse martialske metaforer og sygdomsmetaforer, der virker skræmmende, og i det hele taget mange emotionelt ladede udtryk. Stilen er desuden meget dramatiserende: Han går helt tæt på læseren ved i rigt mål at benytte sig af apostrofe, retoriske spørgsmål og imperativer, gerne efterfulgt af et eller flere udråbstegn. Et eksempel på brug af patos og apostrofe kan hentes i dimisprædikenen, hvor Grundtvig tiltaler den unge, hovmodige prædikant med ordene:

o saa bæv dog tilbage for den rystende Sandhed, at den Bedrøvedes Suk og den Trøsteløses Jammer, den Fortvivledes Skrig og den Døendes Angest vil komme over Dig, vil anklage dig for den Almægtiges Trone, og du, du skal da skiælvende raabe: falder over mig, skiuler mig I Høie, og I Bierge, for den retfærdige Dommer! (Grundtvig 1810, 23).

De ovennævnte træk ved stilen samt Grundtvigs brug af emfase, dels i form af mange gentagelser, dels typografisk ved en meget omfattende brug af fremhævelsesmidlet spatiering, er udtryk for, at han forsøger at yde en kraftig påvirkning og styring af læseren. Stillejet i de polemiske passager er ofte højt (han vil bevæge), ${ }^{15}$ og den stiltype, der anvendes i angrebene og advarslerne, kan med den klassiske retoriks begreber karakteriseres som voldsom og streng (Hermogenes 1987) eller med moderne begreber som polemisk og provokerende (Klujeff 2012).

Den grove stil har også en etosappel, idet den skal vise, at Grundtvig taler og i det hele taget agerer i Luthers ånd. Med stilen "performer" han

Han tilslutter sig jo grundlæggende de mere romantiske værdier som det konkrete, det originale, historien, og her passer logikken ikke særlig godt ind (om argumentation ud fra romantiske vs. klassiske værdier, se Perelman 1979).

15 Jf. Ciceros inddeling af stillejer i den lave, den mellemste og den høje stil, hvis funktion det er hhv. at belære (docere), underholde (delectare) og bevæge (movere). 
sin lutherske identitet, og det virkede faktisk på visse dele af publikum. Præsten Victor Bloch skrev, at Grundtvigs kombination af hårde ord og brændende iver gør ham til "en ægte Broder til Luther" (1840, 237). Det skal nævnes, at stilen i disse polemiske tekster ligger ret langt fra det, der ofte omtales som den typiske grundtvigske stil, nemlig den jævne, gemytlige, lave stil (jf. fx Albeck 2006, 105).

Sammenfattende kan det siges, at Grundtvig med sin polemiske adfærd i årene 1810-1815 gang på gang overskred genrenormerne. Han anvendte de undersøgte genrer - prædikenen, landemodetalen og historiebogen væsentlig mere polemisk, end samtidens normer tilsagde. Han var godt klar over, at han var grænseoverskridende, i hvert fald i retrospektiv. I det tidligere nævnte brev til Molbech skriver han, at han ved sit forsøg på at tvinge verden til at være kristen "gjorde Vold paa alle Former" (Grundtvig og Molbech 1888, 140). Samtiden reagerede da også ofte med forargelse på hans værker, og han fik flere sager på halsen. Dimisprædikenen førte til en omfattende klagesag og en irettesættelse af Grundtvig ved rektor ved Københavns Universitet Thomas Bugge, der bemærkede, at Grundtvig røbede "en forfængelig Attraa efter at vække Opsigt" (citeret efter Nielsen 1889, 111). Talen "Om Polemik og Tolerance" førte til et alvorligt sammenstød med biskop Friederich Münter og endnu en irettesættelse, og kun fordi talen forblev utrykt, undgik Grundtvig den helt store storm. Endelig mødte $V K 1812$ massiv kritik fra den kulturelle elite og gav anledning til flere pennefejder.

\section{Stridsskriftet - en overset genre}

Stridsskriftet er en oplagt genre at undersøge nærmere, når man interesserer sig for polemik. ${ }^{16}$ Det er ellers en genre, som er blevet stedmoderligt behandlet i forskningen, formentlig af flere grunde. For det første føler

\footnotetext{
16 Når betegnelsen 'stridsskrift' er valgt her frem for betegnelser som 'pamflet' eller 'kampskrift', er det for det første, fordi 'stridsskrift' er den betegnelse, Grundtvig selv bruger. Han taler således om "kirkelige Stridsskrifter" (Grundtvig 1840, 649), "aandelige Strids-Skrifter" (Grundtvig 1999, 587) og "personlige Strids-Skrifter" (Grundtvig 1827b, 51). For det andet er det, fordi stridsskriftet indgår i en personlig polemik om et emne og således er smallere og mindre politisk-agiterende end pamfletten og kampskriftet.
} 
mange et ubehag ved polemisk retorik. Lige siden antikken har polemiske genrer som fx invektivet været betragtet som brud på de retoriske normer. Polemisk retorik og smæderetorik regnedes ikke for forbilledlig, men snarere foragtelig pga. sin heftige entusiasme og mangel på kunstfærdighed. ${ }^{17}$ For det andet er der mange, der mener, at stridsskrifternes lejlighedskarakter gør dem uinteressante uden for deres kontekst (jf. Rohner 1987, 10). Den påtrængende nødvendighed, der oprindeligt var omkring en polemik, kan ikke altid mærkes på tidslig afstand, og polemiske tekster har dermed svært ved at overleve deres oprindelige retoriske situation. Stridsskriftet, både det litterære og det teologiske, synes af ovennævnte årsager at være en genre uden megen kulturel prestige. Når jeg alligevel finder stridsskrifterne interessante, er det, fordi der er meget på spil, ikke kun i forhold til forfatterens ære, men også i forhold til den sag, der diskuteres. Sagen er på en måde mere påtrængende i polemiske end i andre mere systematiske genrer, og selvom et polemisk diskussionsklima ganske vist kan være giftigt, kan det faktisk også være frugtbart, da det virker igangsættende på publikum. Polemik og provokation konstituerer et engageret og reflekteret publikum og giver en livlig debat. ${ }^{18}$

Genren 'stridsskrift' er ikke let at definere, selv retoriske ordbøger kvier sig ved det, ${ }^{19}$ men man kan sige så meget, at det er en pjece eller mindre afhandling, som indgår i en polemisk meningsudveksling mellem to personer. Det er en reaktiv genre, idet forfatteren til et stridsskrift typisk reagerer på en anden tekst, det kan være en artikel, anmeldelse el.lign. Forfatteren åbner enten offensivt eller defensivt. Enten anklager han en person, fordi denne har givet udtryk for en position, som han er imod, eller også forsvarer han sig mod et angreb, det kan være en faglig kritik

${ }_{17}$ Jf. at Aristoteles i sin gennemgang af den epideiktiske genre fokuserer på lovtalen frem for dadeltalen. Han finder det ikke nødvendigt at gennemgå dadeltalen $\mathrm{i}$ detaljer, da dens teknik blot består $\mathrm{i}$ at vende lovtalen på hovedet (Aristoteles 2007, 68-76). Dadeltalen er 'lovtalens sorte tvilling' (Roer og Klujeff 2011, 15).

${ }_{18}$ Marie Lund Klujeff, som forsker i stil, argumenterer således for, at provokerende stil både har en benign og en malign side. Engagement og aktivitet er de positive resultater af provokation, mens det på negativsiden tæller, at engagementet fremmes i et sammenstød med andre centrale værdier i offentlig debat, nemlig tolerance og anerkendelse af andres meninger (Klujeff 2012).

${ }^{19}$ I artiklen "Streitschrift" i Historisches Wörterbuch der Rhetorik kaldes genren således en kategori, der er "schwer faßbar". 
eller en personlig fornærmelse, som han ikke vil sidde overhørig (Khorasani 2009, 123). ${ }^{20}$

Stridsskriftet er i udgangspunktet personligt, idet forfatteren skriver til en navngiven person, men man skal være opmærksom på, at denne ikke er den egentlige modtager. Han eller hun skal snarere forstås som et polemikobjekt. Den egentlige adressat er læsepublikummet, som er dem, der skal påvirkes. Selvom det brede læsepublikum ikke altid adresseres direkte af forfatteren, er det dem, som er de primære modtagere. Det er dem, skribenten er ude på at vinde over på sin side og evt. ophidse imod modstanderen. Fordi en polemisk tekst på denne måde er henvendt både til en navngiven person og et bredt publikum, kan man tale om, at kommunikationen ikke er dialogisk, men trialogisk (Stenzel 1986; Jørgensen 1995).

Stridsskriftet kan siges at være en blanding af alle de tre klassiske aristoteliske genrer: Der er træk af den deliberative genre, idet der er en sag, man ønsker at drøfte, og evt. noget bestemt, man vil opnå i fremtiden. Der er træk af den forensiske genre, idet man skiftevis anklager modparten og forsvarer sig selv, og endelig er der træk af den epideiktiske genre, idet man dadler sin modstander på en måde, så man 'fremviser' sin retoriske kunnen (jf. Aristoteles 2007, 42). Grundtvig er selv inde på dette, når han siger, at et stridsskrift er lagt an på både at overbevise, gendrive og forbitre (Grundtvig 1865, 419). I den retoriske genreteori siger man, at en genre udspringer af et socialt behov og har en bestemt funktion (Miller 1984). Stridsskriftets funktion er at give parter, der er uenige, mulighed for hver især at udtrykke deres synspunkter, ytre kritik af modparten og tage til genmæle imod beskyldninger. Det overordnede mål for en pennefejde er altså ikke, at de to modparter bliver enige, men at holdninger bliver markeret og fronter trukket op, sådan at (læse)publikummet kan tage stilling og eventuelt vælge side. Dertil kommer så underholdningsværdien. Det kan være forbundet med nydelse og skadefro at overvære den kamp på liv og død, der udspiller sig i en polemik (Felman 1979, 188; Stenzel 1986, 3).

Hvad angår selve debatformen i en polemisk meningsudveksling, er der grundlæggende to fremgangsmåder: ${ }^{21}$ Der er den saglige debatform, hvor man søger at opnå publikums tilslutning vha. argumenter, svarende

20 Der kan også være tale om et stedfortrædende forsvar, hvor forfatteren føler sig kaldet til at forsvare en anden person eller en institution.

21 For en mere omfattende gennemgang af forskellige typer polemik, se Dascal (2004; 2010). 
til retorikkens ideal om deliberation, dvs. rådslagning. Der gælder en hel række normer og uskrevne regler for den saglige debatform, bl.a. de helt grundlæggende regler, at udsagn skal være sande; at man skal begrunde sine udsagn; at den, der kritiserer, skal løfte bevisbyrden (onus probandi), og at man bør undgå fejlslutninger og personangreb (argumenter ad hominem). ${ }^{22}$

Den anden debatform er den eristiske. ${ }^{23}$ Den adskiller sig fra den deliberative debatform på flere punkter. Hvor den deliberative er dialogisk-argumenterende, er den eristiske mere agiterende og evt. også diffamerende. Den eristiske debattør er mere optaget af at promovere sine egne meninger og af at nedgøre modparten end af at føre egentlige argumenter i marken. Debatten ses som en kamp, man går ind i for at vise, at man har ret, og for at vinde over sin modstander. Den eristiske debattør har egentlig ikke et $ø$ nske om at lytte til den anden. Hans position er fastlåst og lukket af for alt udefrakommende. I stedet for saglige argumenter - eller i supplement til disse - vil eristikeren benytte det, Arthur Schopenhauer i den posthumt udgivne afhandling "Eristische Dialektik" 24 har kaldt 'kneb' eller 'kunstgreb'. De mest almindelige 'kneb’ er følgende: ${ }^{25}$

- At overdrive eller generalisere modstanderens synspunkt

- At tirre modstanderen, så han fremstår tåbeligt vred

- At aflede diskussionen, at tale udenom

- At drage falske følgeslutninger

- At latterliggøre modstanderen over for publikum - argumentum ad auctores

- At påberåbe sig autoriteter

22 Disse normer er, hvad en forskergruppe, som har kortlagt normerne for lærde kontroverser i det moderne Europa (1600-1800) på baggrund af et omfattende empirisk materiale, har kaldt en 'common sense-teori' om kontroverser. Mere udførlige lister over normerne kan findes hos Fritz (2008, 111 f.) og Khorasani (2009, 129).

23 Ordet eristik kommer fra det græske êpı inde i den græske mytologi, dels betyder strid, skænderi og kappestrid. Tilsvarende

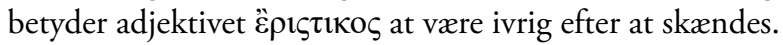

24 På dansk udgivet under titlen Kunsten altid at få ret (Schopenhauer 2006).

25 Dette er blot 10 af de i alt 38 kneb, Schopenhauer (2006) oplister. 
- At erklære sig ude af stand til at forstå modstanderens argumenter, hvorved man insinuerer, at han er fuld af vrøvl

- At bruge værdiladede ord

- At sætte modstanderens synspunkt ind i en forhadt kategori

- At blive personlig, fornærmende, krænkende, grov - argumentum ad hominem

Disse 'kneb' regnes for illegitime i en saglig diskussion.

\section{Grundtvigs teologiske stridsskrifter}

De teologiske stridsskrifter, jeg har nærlæst, er dem, der indgik i Grundtvigs fejder med hhv. Christian Molbech (1813), H.C. Ørsted (1814-1815) og H.N. Clausen (1825). Der er kun plads til at beskrive fejderne ganske kort her og derefter opsummere resultaterne af analyserne.

Striden med Molbech angik historiesyn og historieskrivning. Molbech kritiserede Grundtvig for, at hans historieskrivning i $V K 1812$ var for teologisk og polemisk. Han fandt, at $V K 1812$ var en upassende form for genreblanding: "Ved sin halv historiske, halv polemiske Natur, ere [den] ingenting Heelt" (Molbech 1813, 13). Ifølge Molbech måtte en historie slet ikke være polemisk - enten fortæller man, eller også disputerer man. Han siger til Grundtvig: "At Historie og Polemik ere heterogene Ting, synes det, som du ikke vil vide af" $(1813,14)$. Grundtvig forsvarede sig først i Krønikens Gienmale, derpå fulgte flere små polemiktekster og private breve, og resultatet blev, at de to skiltes som uvenner. De talte ikke sammen de næste 13 år.

Striden med H.C. Ørsted berørte flere emner, bl.a. Grundtvigs person, forsvarlig brug af Bibelen, forholdet mellem religion og videnskab og spørgsmålet om, hvorvidt Schellings filosofi var forenelig med kristendommen. Anledning til striden var Grundtvigs udgivelse af En markelig Spaadom, ogsaa om Dannemark efter en gammel Haandskrift (1814a). Det var et dokument bestånde af en samling af Bibelens spådomme om Antikrist, som Grundtvig havde fundet i sin fars efterladte papirer. Grundtvig fik i sin udlægning spådommene til at passe på Napoleon. H.C. Ørsted anmeldte spådomsskriftet anonymt og skrev, at Grundtvigs eksegese var helt forrykt, og at han var en fjende af fornuften og en falsk profet ([Ørsted] 1814a). Grundtvig svarede straks med stridsskriftet Hvem er den fal- 
ske Profet? (1814b) og senere med Imod den lille Anklager (1815). I disse to tekster kritiserede han bl.a. naturvidenskaben for at lede væk fra religionen, og han insisterede på, at videnskaben skulle tjene troen.

Striden med H.N. Clausen angik kirkesynet og indledtes med Grundtvigs angreb på Clausen i Kirkens Gienmale i 1825. Grundtvig pegede på det paradoksale i, at Clausen regnede Bibelen for kirkens grund og norm, samtidig med at han forholdt sig historisk-kritisk til den og i visse dele satte spørgsmålstegn ved dens ægthed. Grundtvig fandt i stedet den sikre grund for kirken i trosbekendelsen. De fleste Grundtvig-forskere har læst Kirkens Gienmale med en interesse i Grundtvigs formulering af den kirkelige anskuelse, ${ }^{26}$ og på længere sigt blev det da også formuleringen af kirkesynet, der fik teologisk relevans, men Kaj Baagø har ret, når han skriver, at eftertiden har tillagt Kirkens Gienmale en positiv betydning, det slet ikke havde i samtiden $(1958,56)$. Når man undersøger tekstens situation og retorik, så fremstår Kirkens Gienmale ikke som en saglig præsentation af den kirkelige anskuelse. Det er derimod Grundtvigs polemiske intention med teksten og dens ditto form, der påkalder sig opmærksomhed. Grundtvig udfører to centrale talehandlinger med Kirkens Gienmele: Han erklærer højtideligt H.N. Clausen for en "falsk Lærer" (dvs. kætter), og han opfordrer myndighederne til at indføre et "Tolerance-Edikt", sådan at det blev muligt at udelukke Clausen af statskirken, uden at det ville få borgerlige følger. Det var dét, Grundtvig ville opnå med udgivelsen af Kirkens Gienmale i 1825. Clausen nægtede som bekendt at svare Grundtvig og gik i stedet rettens vej for at få ham dømt for injurier.

Mine analyser af de ovennævnte stridsskrifter har vist, at Grundtvigs debatform er af den eristiske type, hvilket egentlig blot er en konsekvens af hans absolutte standpunkt i trosspørgsmålene. Han går ind og ud af fejderne overbevist om, at han har ret. Han er ikke modtagelig for modstanderens indvendinger, og der er således lukket af for dialog på forhånd. Grundtvig benytter sig også ofte af de ovennævnte kneb eller kunstgreb som fx overdrivelser, udskiftning af stridsspørgsmålet og brug af værdi-

26 Pontoppidan Thyssen mener fx, at den formelle polemik ved Kirkens Gienmale 'overskyggedes' af Grundtvigs nye kirkesyn (1983, 230), og Nørager Pedersen skriver, at selve angrebet ikke har nogen interesse, det har kun den position, hvorudfra det føres $(1980,306)$. 
ladede ord. Det er faktisk noget, som Ørsted påtalte flere steder. ${ }^{27}$ Især Grundtvigs fordrejninger irriterede Ørsted så meget, at han i sit stridsskrift Imod den store Anklager valgte at lade polemikkens tidligere akter genoptrykke som en del af skriftet, forsynet med linjetælling, sådan at han kunne referere præcist til, hvem der tidligere havde sagt hvad, og det derved kunne blive tydeligt for læserne, at Grundtvig havde fordrejet hans udsagn (Ørsted 1814b).

Ud over de argumentative 'kneb' benytter Grundtvig sig af forskellige andre polemiske strategier i sine stridsskrifter som $\mathrm{fx}$ antitetisk opbygning og etablering af en stærk modsætning mellem sig selv og modstanderen. Han er selv den gode og fredelige kristne (vir bonus), mens modstanderen er aggressoren (vir malus). ${ }^{28}$ Grundtvig bruger flere steder den bibelske analogi, at han er David og hans modstander Goliat. Derved fremstiller han modstanderen som en fjende, det er legitimt at bekæmpe. Indimellem tyer Grundtvig også til skældsord og ad hominem-argumenter. Det gør han især i angrebet på H.N. Clausen, som han kalder en kætter, løgner og falsk lærer, og hvis teologi han omtaler nedsættende som "Griller", "Daarekiste-Snak" og "Vrævl”, som det ligefrem koster "Overvindelse at afskrive [dvs. gengive]" (1825a, 45, 41, 13). Clausens tro er "naragtig" og hans synspunkt generelt et "latterligt Sværmerie" $(18,20)$. Han er en tåbelig rationalist, som stræber efter at blive "Selv-Eier i Selvmodsigelsens grændseløse Rige” (1). Kritikken af Clausen i Kirkens Gienmale er så personlig og nedsættende, at skriftet nok bedst kan beskrives som en mellemting mellem et stridsskrift og et smædeskrift. Clausen fik da også efterfølgende rettens ord for, at der var tale om "fornærmelige Udladelser". ${ }^{29}$

Alle de tre fejder, jeg har undersøgt, er desuden præget af en eskalationslogik. Indlæggene blev flere og flere, og de blev længere og længere. Grundtvig var ikke den, der neddroslede en strid, men tværtimod den,

27 Ørsted omtaler disse manøvrer som “Kunstgreb” og "Spring” (1814a, 192) eller "Kneb” og "Udflugter" (1814b, 122, 123).

28 I fejden med Ørsted beskriver han fx, hvordan Ørsted er udrustet med farlige våben ("med gloende Jern i Haand, stævner han mod mig, og siger det frit, han vil indbrænde Skiændsels Mærke i min Pande, han spænder sin Bue af Jern og ryster sit Kaagger, saa det gnistrer af de gloende Pile"), mens det eneste, Grundtvig selv har at kæmpe med, er Guds ord, tro og håb (Grundtvig 1814b, VI f.). Det er med andre ord en ulige kamp mellem fysisk magt og ånd.

29 Domsafsigelsen er optrykt hos Dam (1999). 
der søgte konfrontation igen og igen. Det var også altid ham, der fik det sidste ord i pennefejderne (i hvert fald den offentlige del af dem). Han blev ihærdigt ved med at tage til genmæle, mens hans modstandere før eller siden trak sig. Fejderne endte aldrig med forbrødring, men førte til brud hver gang.

Som genre er stridsskriftets funktion, som nævnt, at give folk mulighed for at ytre kritik af en sag eller person eller tage til genmæle. Grundtvig gjorde flittigt brug af genren, men han anvendte den mere eristisk, end normen tilsagde, bl.a. med mange personangreb. Han anvendte genren til at smæde og udgranse sin modstander, tydeligst med H.N. Clausen, på hvem han ligefrem begik et karaktermord. ${ }^{30}$

\section{Samlet vurdering af Grundtvigs polemiske retorik}

Min undersøgelse har vist, hvor gennemsyret af polemik Grundtvigs tekster var i perioden 1810-1825. Den polemiske tendens slår igennem i nærmest alle genrer, og det er ikke bare Grundtvigs stil, der er polemisk, det er hensigten, selvfremstillingen, relationen til publikum, strategierne, argumentationen osv. Det er simpelthen hele tankegangen og fremgangsmåden, der er polemisk.

I retorikfaget er der tradition for, at man i en analyse og kritik også tillader sig at vurdere retorikken i de tekster, man undersøger. Retorik er grundlæggende et normativt fag med en holdning til, hvad der er god og dårlig retorik. De kriterier, man normalt bedømmer ud fra, går på, om retorikken er passende til emnet og formålet; om den er effektiv, dvs. om den overbeviser publikum eller i det mindste opnår en vis grad af tilslut-

30 Kenneth Burke, som er én af den moderne retoriks fædre, er bl.a. kendt for at definere sprog som symbolsk handlen (1969, 42 f.). Forstået som symbolsk handling er Kirkens Gienmale ikke alene et 'kættermageri', som Grundtvig selv kaldte det, men et symbolsk drab. Grundtvig ønskede inderligt et opgør med rationalismen, og i Kirkens Gienmale angreb han "den første Rationalist, der vovede sig i Marken” (Grundtvig 1871, 383), og gjorde ham til syndebuk. I en kladde til Kirkens Gienmale formulerede Grundtvig det sådan, at hvis Clausen ikke kunne bevise sin arveret til kirken, måtte han "nøjes med en lille Kjætter-Begravelse i Kirkehistoriens Baggaard” (citeret efter Brandt 1877, 723). Grundtvig blev efterfølgende klar over, at omgivelserne stemplede ham som en "Mand-Draber" pga. Kirkens Gienmale (Grundtvig 1827a, 39). 
ning eller identifikation; og endelig om retorikken er redelig, dvs. om den er etisk forsvarlig.

Min vurdering er, at den polemiske stil, som Grundtvig benyttede i mange af sine tekster, til dels kan siges at være passende ift. emnet og formålet. Når man vil vække opmærksomhed, udtrykke indignation og animere folk til akut at tage stilling til en sag, så er provokation og polemisk stil et godt middel til at engagere folk (Klujeff 2012). Det afgørende for, om man bliver hørt og taget alvorligt, er imidlertid, om man holder den rette balance. Går man for vidt og overskrider normerne ved at blive for brutal, kan man ikke opretholde en høj etos, men diskvalificerer sig selv som taler eller skribent. Samtidens reaktioner viser med al tydelighed, at Grundtvig gik for vidt.

Grundtvigs polemiske retorik var også kun delvist effektiv i perioden 1810-1825. Han fik folks opmærksomhed, men han fik ikke overbevist ret mange om, at de skulle tilslutte sig hans kamp for den gammellutherske tro. Han formåede ikke at finde og bruge de midler, der kunne overbevise. ${ }^{31}$ Med et udtryk af retorikeren Edward Corbett (1969) er Grundtvigs retorik ikke den åbne hånds retorik, men den knyttede næves. ${ }^{32}$ Hans retorik er uforsonlig, og han anvendte tvingende sproglige midler i stedet for at søge tilslutning og identifikation. Corbett siger følgende om den begrænsede effekt af 'den knyttede næves retorik': "Shouts, threats, obscenities do gain attention. Whether they elicit conviction or action from anyone not already committed to the speaker's point of view is another matter" $(1969,295)$. Det er lige præcis det, der er situationen for Grundtvig i 1810-1825. Med sin polemiske retorik fik han opmærksomhed, skabte sensation, solgte en masse eksemplarer af sine skandaleskrifter og blev i en vis forstand berømt og berygtet, men han opnåede ikke tilslutning til

${ }^{31}$ Netop sådan defineres retorikken hos Aristoteles: Retorik er "den kunnen, der sætter os i stand til at mønstre de mulige overbevisende momenter i et givent stof" $(2007,33)$. Persuasio var nøglebegrebet i den antikke retorik, mens moderne retorikere som Chaïm Perelman og Kenneth Burke er bevidste om, at man ikke altid kan overbevise sit publikum helt og aldeles. For dem består retorikkens opgave i at søge identifikation med tilhørerne og opnå deres tilslutning (i større eller mindre grad).

32 Udtrykkene 'den åbne hånd' og 'den knyttede næve' stammer oprindeligt fra filosoffen Zenon, som anvendte dem om stil. Corbett (1969) giver udtrykkene en drejning, når han lader dem stå for en aggressiv, provokerende retorik vs. en imødekommende, forsonlig retorik (Jørgensen 2009, 133). 
sine synspunkter fra andre end dem, der var enige med ham i forvejen, og i den forstand var han ikke en dygtig retoriker. Det lykkedes ham ikke at bevæge den mere modvillige del af publikum i retning af sin egen overbevisning. ${ }^{33}$

Hvad angår den polemiske retoriks redelighed, må det konkluderes, at Grundtvig havde svært ved at holde sig til en saglig debatmåde. Især i de personlige fejder anvendte han uredelige midler som overdrivelser, urimelige generaliseringer, fordrejninger af modstanderens synspunkter og skældsord. Med sine mange og intense personangreb overskred han normerne, men det skal retfærdigvis siges, at hans modstandere også gjorde det indimellem. Ingen af dem kunne sige sig fri for at ty til ad hominem-argumenter i fejderne, selvom de var enige om, at det var forkert. Som Grundtvig siger i en lille fejde fra 1809: "Jeg holder mig til Mandens Bog / Og holder mig fra Bogens Mand, / Undtagen der hvor Bog og Mand / Ei længere adskilles kan” (1809, 517). I praksis lykkedes det sjældent at holde mand og bog adskilt særlig længe ad gangen.

\section{Kristen stridsmand - et oxymoron?}

Spørgsmålet om den polemiske retoriks etiske forsvarlighed bliver sat på spidsen i en kristen sammenhæng. Den kristne stridsmand er en kendt kirkehistorisk figur, men ikke desto mindre kan man stille spørgsmål ved, om rollen er forenelig med kristen etik, for den kristne polemiker dyrker jo alle de modsatte værdier og principper af kristendommen: hån, fjendskab og latterliggørelse frem for ydmyghed og broderkærlighed. Som flere af Grundtvigs samtidige påpegede over for ham, er den polemiske adfærd svær at forene med fx Bjergprædikenen, som ingen plads levner for aggression, hverken i ord eller handling (jf. især Matt 5,21-26.39).

Når Grundtvig taler om at være herrens eller Jesu Kristi stridsmand, refererer han direkte eller indirekte til 2 Tim 2, men det er, som om han har

33 Det 'uretoriske' ved Grundtvig stemmer sådan set godt med den afstandtagen fra retorikken, som man møder enkelte steder i hans tekster. Han vendte sig således imod den "konstlede Veltalenhed" hos Christian Bastholm (1812b, 338) og erklærede i Bibelske Pradikener (1816), at en prædiken ikke bør være et "Veltalenhedens Konstverk" (IX). Han tog tilmed afstand fra de "tomme Rhetor-Vendinger”, der måtte være at finde i hans egen dimisprædiken (XXXII). 
glemt at læse kapitlet til ende, for der følger en række formaninger, som burde være nok så vigtige og styrende for den kristnes adfærd:

Hold dig fra de tåbelige og hidsige diskussioner; du ved, at de kun fører til stridigheder, og en Herrens tjener skal ikke strides med nogen. Han skal være venlig mod alle, være en god lærer og finde sig i ondt. Han skal med mildhed irettesætte dem, der siger imod" (v. 23-25, mine fremhævelser).

Jeg mener, at der er grund til at være kritisk over for Grundtvig i skikkelsen af herrens stridsmand, både hvad angår hans teologi og hans polemiske fremgangsmåde. Hans teologi i perioden 1810-1825 er problematisk, både fordi den rummer mere lov end evangelium, og fordi den har karakter af at være en skråsikker påstandsteologi, man ikke kan diskutere med. ${ }^{34}$ En retorisk tilgang til teologien giver en bevidsthed om, at sandheden 'i sig selv' ikke er nok. Den kan ikke bare postuleres, hvis man gerne vil opnå tilslutning hos sit publikum. Også teologer må argumentere for deres synspunkter og bibeltolkninger og forsøge at gøre det kristne budskab persuasivt over for det konkrete publikum. Det er ikke nok at råbe det ud fra tagene, hvis det skal have effekt. ${ }^{35}$

Den polemiske fremgangsmåde er, som nævnt, generelt problematisk, fordi den ikke er særlig effektiv, og fordi den nemt slår over i en uredelig form for kommunikation, men i en kristen kontekst er det største problem nok, at den er utroværdig. Det er ganske enkelt ikke troværdigt at forkynde Guds kærlighed og frelse vha. hadefuld tale og trusler. En grov og hadsk tone diskrediterer den sag, man hævder at tjene (Timms 1995, 113).

\section{Fra stridsmand til landsfader}

Læser man Grundtvigs tekster fra perioden 1810-1825, står det klart, hvor konsekvent polemisk og nærmest fanatisk han var i denne periode, og hvor alene han af den grund kom til at stå i samtiden. Grundtvigs polemiske

\footnotetext{
34 Jf. Jan Lindhardts artikel “Den principielle påståelighed” (1997), som kritiserer den teologiske tendens til påstandsretorik.

35 Dette er hovedsynspunktet i David Cunninghams bog Faithful Persuasion. In Aid of a Rhetoric of Christian Theology (1991).
} 
fremfærd fik store konsekvenser for hans liv. Dimissagen var medvirkende til hans psykiske sammenbrud i 1810-1811, og den generelle uvilje mod ham fik ham hele to gange til at nedlægge sit præsteembede i hhv. $1815 \mathrm{og}$ 1826. Især kom Kirkens Gienmale til at koste ham dyrt, da han som følge af injuriedommen blev underlagt censur. Grundtvigs polemik må derfor betegnes som et tveægget sværd i den forstand, at han sårede mange med det, men det ramte også ham selv. Hans angreb gav bagslag og ødelagde hans omdømme.

På den baggrund rejser der sig et oplagt spørgsmål, nemlig: Hvordan endte Grundtvig som historiens sejrherre? Hvordan gik han fra så udtalt en outsiderposition, som han havde i 1810-1825, til at blive 'mainstream' og sidenhen ligefrem anset for nationens fader? Hvordan kunne han tabe stort set alle de slag, han udkæmpede i årene 1810-1825, og alligevel vinde krigen? Vandt han mon frem på grund eller på trods af sin polemik? Jeg vurderer, at hans polemik hjalp ham et stykke vej, idet den var med til at gøre ham berømt. Den gav ham et navn - noget, han havde eftertragtet siden sine unge dage som digter. Han ville, koste hvad det ville, være berømt, og da han oven på sagen med Clausen og embedsnedlæggelsen skrev sit Literaire Testamente, konstaterede han tilfreds: "min Pen har virkelig gjort mig navnkundig i Norden” (1827a, III). Men mere end at skaffe opmærksomhed kunne polemikken ikke. Når Grundtvig senere vandt så stor tilslutning, som han gjorde, skyldtes det, at flere forhold ændrede sig. For det første forlod han den dualistiske kristendomsforståelse, som polemikken udsprang af, og indså, at strid ikke var den rigtige vej frem. Der skulle andet til "at oplive den Christne Menighed end Penne-Feider eller Høiesterets-Domme” $(1871,384)$. For det andet begyndte han - motiveret af sine egne vanskeligheder under censuren - at arbejde for frihed i kirken i stedet for at forsøge at tvinge en bestemt form for kristendom igennem. Han blev ganske enkelt mere rummelig med tiden, især fra 1830'erne og frem. Endelig har den apologetiske Grundtvig-fortolkning og -formidling også spillet en rolle i hans 'milde' udbredelse. Hans tilhængere har mere eller mindre bevidst frasorteret, nedtonet og omfortolket den polemiske side af forfatterskabet.

Selvom Grundtvig blev mildere med alderen, forlod den polemiske tilbøjelighed ham nu aldrig helt. Polemikken var ikke lige stærk gennem hele forfatterskabet, men den varede livet ud, og selvforståelsen som herrens stridsmand forblev også intakt. Så sent som i 1867 skrev han: 
Thi til Stridsmand er jeg baaret, Og til Stridsmand er jeg skabt, Dertil Gud mig har udkaaret, Ingen Strid jeg end har tabt. ${ }^{36}$

\section{Litteratur}

\section{Varker af Grundtvig}

Der henvises til førstetrykkene af Grundtvigs værker, hvoraf mange er tilgængelige i den digitale udgave Grundtvigs Verker, udg. af Grundtvig Centeret ved Aarhus Universitet, Aarhus og København (2010-). Værkerne kan tilgås på grundtvigsværker.dk.

- (1809), "Til Hr. Professor Sander", i: Nyeste Skilderie af Kjøbenhavn, nr. 33, 531-519.

- (1810), Hvi er Herrens Ord forsvundet af hans Hus?, København, [J.H. Schubothes Forlag].

- (1812a), Subskriptions-Plan, København, [J.H. Schubothes Forlag].

- (1812b), Kort Begreb af Verdens Krønike i Sammenhang, København, Andreas Seidelins Forlag.

- (1812c), Hvorfor kaldes vi Lutheraner? Pradiken paa Alle Helgens Dag, København, J.H. Schubothes Forlag.

- (1813), Krønikens Gienmale, København, Andreas Seidelins Forlag.

- (1814a), En markelig Spaadom, ogsaa om Dannemark efter en gammel Haandskrift, København, Andreas Seidelins Forlag.

- (1814b), Hvem er den falske Profet? Hvem forvirrer Folket?, København, Andreas Seidelins Forlag.

- (1815a), Imod den lille Anklager, det er Prof. H.C. Ørsted, med Beviis for at Schellings Philosophie er uchristelig, ugudelig og lognagtig, København, Andreas Seidelins Forlag.

36 Citatet stammer fra en kladde til et længere digt med overskriften "Mit Levnetsløb”, her citeret efter Høirup $(1951,17)$. 
- (1815b), "Om Baggesen og om mig”, i: Nyeste Skilderie af Kjøbenhavn, nr. 103, 1633-1640.

- (1816), Bibelske Predikener efter Tidens Tarv og Leilighed, København, J.H. Schubothes Forlag.

- (1817), "Paaske-Lilien", i: Danne-Virke, bind 2, 291-325.

- (1825a), Kirkens Gienmale mod Professor Theologia Dr. H.N. Clausen, København, Den Wahlske Boghandlings Forlag.

- (1825b), Den christelige Kamp, København, Den Wahlske Boghandlings Forlag.

- (1827a), Skribenten Nik. Fred. Sev. Grundtvigs Literaire Testamente, København, Den Wahlske Boghandlings Forlag.

- (1827b), "Om Religions-Frihed", i: Theologisk Maanedsskrift, bind 8, 28-59 og 136-171.

- (1840), "Mit Frisprog og 'de saarede Hjerter”, i: Nordisk Kirke-Tidende, 8. årgang, nr. 43, 691-702.

- (1865), Om den sande Christendom og Om Christendommens Sandhed, 2. udg., København, Karl Schønbergs Forlag.

- (1866/1827), Om Religions-Frihed. (Tredie og sidste Stykke). Slutningen af en Afhandling i Theologisk Maanedsskrift, 8de Bind. Trykt 1827. Undertrykt samme Aar. Løsladt 1866, København.

- (1871), Kirke-Speil eller Udsigt over den christne Menigheds Levnetslob. Efter mundtligt Foredrag 1861-63, København, Karl Schønbergs Forlag.

- (1877), Mands Minde 1788-1838. Foredrag over det sidste halve Aarhundredes Historie, holdte 1838, København, Karl Schønbergs Forlag.

- (1941), "Om Polemik og Tolerance eller om Tvist og Taal”, i: Georg Christensen og Hal Koch (udg.), Verker i Udvalg, bind 2, 93-107.

- (1999), "Om Krig og Fred i Christenheden”, i: Ole Vind, Grundtvigs historiefilosof, København, Gyldendal, 570-591.

Grundtvig, N.F.S. og Christian Molbech (1888), Christian Molbech og Nikolai Frederik Severin Grundtvig. En Brevvexling, udg. af Chr. K.F. Molbech og Ludvig Schrøder, København, Gyldendalske Boghandels Forlag.

\section{Verker af andre forfattere}

Albeck, Ulla (2006), Dansk stilistik, 7. udgave, København, Gyldendal. Aristoteles (2007), Retorik, København, Museum Tusculanums Forlag. 
Auken, Sune og Sunesen, Christel (red.) (2014), Ved lejlighed. Grundtvig og genrerne, Hellerup, Forlaget Spring.

Bitzer, Lloyd F. (1997/1968), “Den retoriske situation”, oversat af Jens E. Kjeldsen i Rhetorica Scandinavica, nr. 3, 9-17.

Black, Edwin (2013/1970), “The Second Persona”, i: Ott, Brian L. og Dickinson, Greg (red.) (2013), The Routledge Reader in Rhetorical Criticism, New York, Taylor \& Francis.

Bloch, J. Victor (1840), "Sammenstilling af Hr. Pastor Grundtvigs Frisprog og Hr. Biskop Mynsters Oplysninger med Hensyn til den polemiske Form”, i: Nordisk Tidskrift for christelig Theologi, bind 2, 229-247.

Brandt, C.J. (1877), “Kirkens Gjenmæle”, i: Dansk Kirketidende, nr. 44, 713-730, og nr. 45, 737-747.

Burke, Kenneth (1969), A Rhetoric of Motives, Berkeley, University of California Press.

Baagø, Kaj (1958), Magister Jacob Christian Lindberg. Studier over den grundtvigske bevagelses første kampe, København, G.E.C. Gads Forlag.

Corbett, Edward P.J. (1969), "The Rhetoric of the Open Hand and the Rhetoric of the Closed Fist", i: College Composition and Communication, bind 20, nr. 5, 288-296.

Cunningham, David (1991), Faithful Persuasion. In Aid of a Rhetoric of Christian Theology, Notre Dame, University of Notre Dame Press.

Dam, Poul (1999), "Noget om Myterne omkring den Clausen'ske injuriesag og Grundtvigs censurperiodes afslutning”, i: Grundtvig-Studier 1999, 7-26.

Danmarks og Norgis Kirke-ritual 1685-1985 (1985), udg. af Udvalget for konvent for kirke og theologi, u.st.

Dascal, Marcelo (2004), "On the Uses of Argumentative Reason in Religious Polemics", i: Religious Polemics in Context. Papers presented to the second international conference of the Leiden Institute for the Study of Religions (LISOR) held at Leiden, 27-28 april 2000, Assen, Royal Van Gorcum, 3-20.

- (2010), "Types of Polemics and Types of Polemical Moves”, i: Capone, A. (red.), Perspectives on Language Use and Pragmatics: A Volume in Memory of Sorin Stati, München, Lincom, 77-97.

Felman, Shoshana (1979), "Le discours polémique (Propositions préliminaires pour une theorie de la polémique)", i: Cahiers de l'Association international des études francaises, bind 31, 179-192.

Foucault, Michel (2001), Fearless Speech, Joseph Pearson (udg.), New York, Semiotext(e). 
Fritz, Gerd (2008), “Communication principles for controversies: A historical perspective", i: Eemeren, Frans H. van og Garssen, Bart (red.) (2008), Controversy and Confrontation: Relating Controversy Analysis with Argumentation Theory, Amsterdam, John Benjamins, 109-124.

Hermogenes (1987), On Types of Style, oversat og udg. af Cecil W. Wooten, Chapel Hill, The University of North Carolina Press.

Høirup, Henning (1951), "Grundtvig i 1867 belyst ved aktstykker og digte fra sygdomsåret”, i: Grundtvig-Studier 1951, 7-68.

Jørgensen, Charlotte (1995), "Debattens væsen og uvæsen. Om fjendtlighed i den offentlige debat”, i: Retorik Studier, nr. 10, 3-43.

- (2009), "Argumentation”, i: Jørgensen, Charlotte og Villadsen, Lisa (red.), Retorik - teori og praksis, Frederiksberg, Samfundslitteratur, 129-158.

Khorasani, Manouchehr Moshtagh (2009), The Development of Controversies: From the Early Modern Period to Online Discussion Forums, Linguistic Insights, bind 91, Bern, Peter Lang.

Klujeff, Marie Lund (2012), "Provocative Style”, i: Kock, Christian og Villadsen, Lisa (red.) (2012), Rhetorical Citizenship and public deliberation, University Park Pennsylvania, The Pennsylvania State University Press, 101-114.

Larson, Paul Merville (1942), A Rhetorical Study of Bishop Nicholas Frederick Severin Grundtvig, doktorafhandling, Evanston, Illinois, School of Speech, Northwestern University.

Lindhardt, Jan (1997), "Den principielle påståelighed”, i: Rasmussen, Anders Moe og Thyssen, Peter (red.) (1997), Teologi og Modernitet, Aarhus, Aarhus Universitetsforlag, 166-177.

Lundgreen-Nielsen, Flemming (1980), Det handlende ord. N.F.S. Grundtvigs digtning, litteraturkritik og poetik 1798-1819, København, G.E.C. Gads Forlag.

McCroskey, James C. (2006), "Ethos: A Dominant Factor in Rhetorical Communication", i: An Introduction to Rhetorical Communication, 9. udgave, Pearson, West Virginia University, 82-107.

Miller, Carolyn R. (1984), “Genre as Social Action”, i: Quarterly Journal of Speech, nr. 70, 61-70.

Molbech, Christian (1813), Til Hr. N.F.S. Grundtvig, Capellan i Udby i Anledning af hans Verdenskrønike og Kjøbenhavns Skilderi No. 29, København, Andreas Seidelins Forlag.

Nielsen, Frederik (1889), N.F.S. Grundtvigs religiøse Udvikling. Et Mindeskrift, København, Karl Schønbergs Forlag.

Nørager Pedersen, A.F. (1980), Prødikenens Idéhistorie, København, Gyldendal. 
Perelman, Chaïm (1979), "Classicism and Romanticism in Argumentation", i: The New Rhetoric and the Humanities. Essays on Rhetoric and its Applications, Dordrecht, D. Reidel Publishing Company, 159-167.

- (2005/1977), Retorikkens Rige. Retorik og argumentation, oversat af Søren Porsborg og Hanne Roer, København, Hans Reitzels Forlag.

Roer, Hanne og Klujeff, Marie Lund (2011), “Temaintro: Smæderetorik”, i: Rhetorica Scandinavica, nr. 57, 9-18.

Rohner, L. (1987), Die literarische Streitschrift. Themen, Motive, Forme, Wiesbaden, Harrassowitz.

Schopenhauer, Arthur (2006), Kunsten altid at få ret. 38 måder at vinde en ellers tabt diskussion, København, Informations Forlag.

Stenzel, Jürgen (1986), "Rhetorischer Manichäismus. Vorschläge zu einer Theorie der Polemik", i: Schöne, A. (udg.), Kontroversen, alte und neue, bind 2: Formen und Formgeschichte des Streitens. Die Literaturstreit, Tübingen, Max Niemeyer, 3-11.

Thaulow, Vanja (2018), Herrens Stridsmand. Retorisk kritik af N.F.S. Grundtvigs teologiske polemik i perioden 1810-1825, ph.d.-afhandling, Aarhus, Institut for Kultur og Samfund, Aarhus Universitet.

Thyssen, Anders Pontoppidan (1983), "Grundtvigs tanker om kirke og folk 182547”, i: Thodberg, Christian og Thyssen, Anders Pontoppidan (red.) (1983), Grundtvig og grundtvigianismen i nyt lys. Hovedtanker og udviklingslinier fra de senere års Grundtvigforskning, Frederiksberg, Anis, 225-286.

Timms, Edward (1995), “The Christian Satirist: A Contradiction in Terms?”, i: Forum for Modern Language Studies, bind xxxi, nr. 2, 101-116.

Toldberg, Helge (1950), Grundtvigs symbolverden, København, Nordisk Forlag.

Vatz, Richard E. (1973), "The Myth of the Rhetorical Situation”, i: Philosophy \& Rhetoric, bind 6, nr. 3, 154-161.

Walzer, Arthur E. (2013), "Parrēsia, Foucault and the Classical Rhetorical Tradition", i: Rhetoric Society Quarterly, 43:1, 1-21.

[Ørsted, H.C.] (1814a), “[Anmeldelse af] En Mærkelig Spaadom, ogsaa om Danmark, efter en gammel Haandskrift udgivet af N.F.S. Grundtvig”, i: Dansk Litteratur-Tidende, nr. 12-13, 177-208.

Ørsted, H.C. (1814b), Imod den store Anklager, København. 